Original article

\title{
Clinical review of COVID-19 patients presenting to a quaternary care private hospital in South India: A retrospective study
}

\author{
Prithvi Mohandas *, Sathya Periasamy, Manimaran Marappan, Arun Sampath, \\ Vanaja Kate Garfin Sundaram, Vijit Koshy Cherian
}

MIOT International Hospital, Chennai, Tamil Nadu, 600089, India

\section{A R T I C L E I N F O}

\section{Keywords:}

COVID-19

Epidemiology

Risk factors

SARS-CoV-2

South India

\begin{abstract}
A B S T R A C T
Background: Coronavirus disease 2019 (COVID-19) has been declared a global public-health crisis due to its impact on health, economy, and mental well-being. Here, we evaluated the clinical and epidemiological parameters associated with COVID-19 in South India.

Methods: A retrospective, quaternary care hospital-based study that included COVID-19 positive patients admitted to MIOT International Hospital, Chennai between 8 April-7 August 2020. Cases were identified by reverse transcriptase-polymerase chain reaction. Epidemiological, demographic, clinical, and radiological findings were recorded and analyzed. The primary endpoint was stable discharge from hospital/patient recovery or death. Associations between risk factors and comorbidities were analyzed using Chi-Square/Fisher's exact test. Results: Of the 5264 cases reviewed, 3345 cases were included. The mean (standard deviation, SD) age of the patients was 47.58 (16.69) years with a median and range hospital stay of 5 (2-41) days. $69.20 \%$ of patients were male. The most frequent comorbidities were diabetes $(37.10 \%)$ and hypertension $(29.10 \%)$. Contact history was available for $58 \%$ of patients. The most common symptoms were cough (36.60\%), fever (28.30\%), and myalgia (15.40\%). Abnormal chest radiography was reported in $16.9 \%$ of patients. Phase of admission, age $\geq 50$ years, hypertension, diabetes, coronary artery disease, chronic kidney disease was significantly associated with mortality $(\mathrm{p}<0.05)$. There were $142(4.2 \%)$ deaths in this study.

Conclusion: In this single centre hospital-based study, late presentation and more severe form of COVID pneumonia lead to higher mortality although it had lower mortality rate for COVID-19 in comparison. Late phase of the pandemic showed better outcomes vs. the early group.
\end{abstract}

\section{Introduction}

The severe acute respiratory syndrome coronavirus-2 (SARS-CoV-2) is a novel species of betacoronavirus family similar to the earlier SARS$\mathrm{CoV}$ and the Middle East Respiratory Syndrome virus (MERS). The disease is characterized mainly by fever, cough, myalgia, and fatigue, with most patients reporting more than one symptom. ${ }^{1}$ It causes severe respiratory distress and cytokine storm in some cases leading to death. The person-to-person transmission rate of this virus is high with a reproduction number $\left(\mathrm{R}_{0}\right)>1$. $^{2}$

The World Health Organization (WHO) has declared the disease a pandemic. ${ }^{3}$ As of January 2021, the global incidence of SARS-CoV-2 was $10,639,684$ confirmed cases and 153,184 deaths. ${ }^{4}$ India has the second-highest cases of coronavirus disease 2019 (COVID-19) in the world as of December 18, 2020. The total number of COVID positive cases in Tamil Nadu stood at 782,915 cases and deaths at 11,954 as of December 19, 2020. ${ }^{5}$ The infection and disease have reached unprecedented levels; in the absence of preventive and specific treatment measures, the medical community in the world is facing challenges in controlling the spread of the virus.

Due to the unique nature of the virus, several treatment options have been explored. The treatment modalities and management of patients are evolving as understanding the virus and its pathogenesis is becoming more apparent. Drugs like steroids, hydroxychloroquine, protease inhibitors like lopinavir and ritonavir, favipiravir, remdesivir, and immunosuppressants are being used to manage the symptoms of COVID$19 .^{6}$ Nevertheless, there is still no established treatment option for SARS-CoV-2.

This study aimed to understand the demographic and clinical characteristics of patients infected with SARS-CoV-2 and evaluate the

\footnotetext{
* Corresponding author. MIOT International Hospital, 4/112, Mount Poonamallee Road, Manapakkam, Chennai, Tamil Nadu, 600089, India.

E-mail address: chairman@miothospitals.com (P. Mohandas).
} 
associations between clinical and epidemiological features of COVD-19 and mortality in a hospital-based setting in South India. Since there is a dearth of published epidemiological data concerning COVID-19 patients in India, this study has potential to partially fill this gap, which could help effectively plan outbreak control measures in the country.

\section{Methods}

\subsection{Study design and objectives}

The MIOT International hospital is a 1000-bed quaternary care private hospital that caters to the population in the metropolitan area of Chennai, Tamil Nadu. Besides the local population, patients are also referred from nearby states and overseas countries. This was a singlecentre, hospital-based retrospective study conducted in Tamil Nadu, India. The case records of all patients admitted to the designated block specifically for COVID patients' admission between April 8, 2020, and August 7, 2020 were reviewed.

The objective of the study was to assess the clinical and epidemiological characteristics of patients with COVID-19, to evaluate the association between different risk factors such as age, gender, comorbidities like diabetes, hypertension, chronic kidney disease (CKD), coronary artery disease (CAD), chronic obstructive pulmonary disease (COPD), hypoxia peripheral capillary grades (mild: oxygen saturation $\left[\mathrm{SpO}_{2}\right]$ 90-95\%; moderate: $\mathrm{SpO}_{2}$ 75-89\%; severe: $\left.\mathrm{SpO}{ }_{2}<75 \%\right),{ }^{7}$ date of admission and outcome of COVID-19.

Admission criteria to the medical block were as follows:

- Confirmed cases: patients who were COVID-19 reverse transcriptasepolymerase chain reaction (RT-PCR) positive.

- Suspected cases: those with symptoms of SARS-CoV-2, contact history or travel history as per Indian Council of Medical Research (ICMR) guidelines at the time of admission.

- Probable cases: COVID-19 RT-PCR negative cases, but who had clinical and radiological features suggestive of COVID-19.

- Asymptomatic cases: COVID-19 RT-PCR positive cases, required admission during the earlier phase of the pandemic as per ICMR and local government guidelines.

- Pre-procedure admissions: those needing any intervention, surgical or medical treatment in other areas were admitted in the medical block, cleared after RT-PCR COVID-19 test, and transferred to the respective areas for further treatment.

Typical chest imaging findings suggestive of COVID-19 included the following - Chest radiography: hazy opacities, often rounded in morphology, with peripheral and lower lung distribution; Chest CT: multiple bilateral ground-glass opacities, often rounded in morphology, with peripheral and lower lung distribution; Lung ultrasound: thickened pleural lines, B lines (multifocal, discrete, or confluent), consolidative patterns with or without air bronchograms. ${ }^{8}$

The categories of COVID-19 cases was defined as asymptomatic or pre-symptomatic, mild, moderate, severe and critical and were defined as follows: ${ }^{9}$

- Asymptomatic or pre-symptomatic infection: Individuals who test positive for SARS-CoV-2 using a virologic test (i.e., a nucleic acid amplification test or an antigen test) but who have no symptoms that are consistent with COVID-19.

- Mild illness: Individuals who have any of the various signs and symptoms of COVID-19 (e.g., fever, cough, sore throat, malaise, headache, muscle pain, nausea, vomiting, diarrhoea, loss of taste and smell) but who do not have shortness of breath, dyspnoea, or abnormal chest imaging.

- Moderate illness: Individuals who show evidence of lower respiratory disease during clinical assessment or imaging and who have peripheral capillary saturation of oxygen $\left(\mathrm{SpO}_{2}\right) \geq 94 \%$ on room air at sea level.

- Severe illness: Individuals who have $\mathrm{SpO}_{2}<94 \%$ on room air at sea level, a ratio of arterial partial pressure of oxygen to fraction of inspired oxygen $(\mathrm{PaO} 2 / \mathrm{FiO} 2)<300$, respiratory frequency $>30$ breaths/min, or lung infiltrates $>50 \%$.

- Critical illness: Individuals who have respiratory failure, septic shock, and/or multiple organ dysfunction.

Records of cases that met the case definition and for whom the demographic, epidemiological, and clinical parameters were documented in the medical records were included. Records with incomplete information and for which any of the inclusion criteria or case definition were not met were excluded from this study. Patients unwilling for admission or those who refused treatment for COVID-19 in the hospital were also excluded from the study. Outcomes of patients discharged against medical advice were done by contacting the attenders of the patients on telephone.

This study was approved by the institutional ethics committee and the local ethics committee and conducted in accordance with the Declaration of Helsinki.

\subsection{Statistical analysis}

Continuous variables were summarized with mean, standard deviation (SD), minimum, and maximum values. Categorical variables were descriptively summarized with percentages. Proportions of patients with data on clinical symptoms, investigations, treatments, outcomes were summarized. Associations between the date of admission (early: April 2020 to June 2020; late: from June 2020 to August 2020) and the end point were recorded (recovery vs. mortality), sociodemographic variables/comorbidities, symptoms, investigations/treatments with the recorded outcome (dead vs. alive) were analyzed. Pearson Chi-Square test and Fisher's exact test were used as appropriate, based on the distribution, and p-values were tabulated with a level of significance set at $<0.05$.

A sub-group analysis investigated the association between variables of interest such as hypertension, diabetes, CKD, CAD, COPD, hypoxia and deaths stratified by date of admission (early, April 8, 2020 to June $20,2020 v s$. late, from June 21, 2020 to August 7, 2020), age group $<50$ vs. $\geq 50$ years.

\section{Results}

A total of 5264 charts were reviewed during the study. Of these, 3345 confirmed cases of COVID-19 were identified and included in the study. A total of 1918 cases were excluded since they were admitted for other procedures $(n=443)$, tested as COVID-19 negative $(n=1918)$, and those who stayed $<48 \mathrm{~h}$ in the medical block $(\mathrm{n}=1475)$. More than half $(69.2 \%)$ of the patients were males. The mean (SD) age of the cohort was 47.58 (16.69) years. The majority $(98.20 \%)$ of the admissions were from Tamil Nadu. The median duration of hospital stay was 5 (2-41) days. Socio-demographic and patient baseline characteristics are summarized in Table 1.

\subsection{Clinical and epidemiological characteristics of COVID-19 patients}

The most frequently reported comorbidities were hypertension (29.10\%), diabetes (37.10\%), CKD (1.60\%), CAD (6\%) and COPD $(0.20 \%)$. More than half of the patients $(58 \%)$ had a report of contact history. Travel history was reported in only $0.70 \%$ of patients. The most common symptoms observed were cough $(36.60 \%)$, fever $(28.30 \%)$, myalgia (15.40\%), and gastrointestinal symptoms (15\%) (Fig. 1). Breathing difficulty $(10.40 \%)$, headache $(9.70 \%)$, sore throat $(8.60 \%)$, and loss of taste and smell (7.40\%) were infrequent. Asymptomatic infection was observed only in $28.20 \%$ of patients. $\mathrm{SpO}_{2}$ grades mild, 
Table 1

Demographic and clinical characteristics.

\begin{tabular}{ll}
\hline Parameter & Value \\
\hline Age, years $(\mathrm{n}=3345)$ & $47.58 \pm 16.69$ \\
Gender $(\mathrm{n}=3345)$ & \\
$\quad$ Female & $1031(30.80)$ \\
$\quad$ Male & $2314(69.20)$ \\
Inpatient stay & \\
Total number of days $(\mathrm{n}=3345)$ & $5(2-41)$ \\
Temperature $\left({ }^{\circ} \mathrm{F}\right)(\mathrm{n}=3345)$ & $98.37 \pm 1.09$ \\
Oxygen saturation $(\mathrm{n}=3345)$ & $96.12 \pm 5$ \\
Hemoglobin $(\mathrm{g} / \mathrm{dL})(\mathrm{n}=2991)$ & $12.97 \pm 1.82$ \\
Platelets $(\mathrm{per} \mathrm{mcL})(\mathrm{n}=3232)$ & $248855.9 \pm 87298.97$ \\
Total WBC count $(\mathrm{per} \mathrm{mcL})(\mathrm{n}=3010)$ & $7374.55 \pm 4602.15$ \\
ESR, 1 h reading $(\mathrm{n}=492)$ & $35.08 \pm 28.93$ \\
C reactive protein $(\mathrm{mg} / \mathrm{dL})(\mathrm{n}=1264)$ & $50.48 \pm 76.9$ \\
Ferritin $(\mathrm{mcg} / \mathrm{L})(\mathrm{n}=1083)$ & $252.89 \pm 252.27$ \\
Interleukin $6(\mathrm{n}=1087)$ & $69.35 \pm 270.9$ \\
LDH $(\mathrm{U} / \mathrm{L})(\mathrm{n}=1123)$ & $268.93 \pm 204.35$ \\
Urea $(\mathrm{mg} / \mathrm{dL})(\mathrm{n}=3290)$ & $28.37 \pm 25.18$ \\
Serum creatinine $(\mathrm{mg} / \mathrm{dL})(\mathrm{n}=3294)$ & $0.81 \pm 0.95$ \\
Total bilirubin $(\mathrm{mg} / \mathrm{dL})(\mathrm{n}=3256)$ & $0.56 \pm 0.36$ \\
Hypertension $(\mathrm{n}=3345)$ & $974(29.10)$ \\
Diabetes $(\mathrm{n}=3345)$ & $1240(37.10)$ \\
Hypothyroidism $(\mathrm{n}=3345)$ & $94(2.80)$ \\
CKD $(\mathrm{n}=3345)$ & $52(1.60)$ \\
Bronchial asthma $(\mathrm{n}=3345)$ & $98(2.90)$ \\
COPD $(\mathrm{n}=3345)$ & $7(0.20)$ \\
CAD $(\mathrm{n}=3345)$ & $200(6)$ \\
\hline
\end{tabular}

Data presented as median range for hospital stay, mean (SD) for other values.

moderate, and severe were observed in $8.80 \%, 3.60 \%$, and $1 \%$ of patients. Abnormal chest X-ray finding was observed in $16.9 \%$ of patients, while chest CT scan COVID-19 pneumonia was reported in $14.3 \%$ of patients. In the early phases of the study, the most frequently administered drugs for the management of COVID-19 were Azithromycin (100\%), hydroxychloroquine (11.50\%), toclizumab (6.90\%), while remdesivir (4.30\%) was used in the later phase of the study to those meeting criteria for usage. Low molecular weight heparin and steroids were administered in $48.60 \%$ and $53.50 \%$ of patients, respectively (Fig. 2). Intensive care unit (ICU) admission was required for $13.20 \%$ of patients. A total of $142(4.2 \%)$ patients died due to COVID-19 in this study. The total deaths reported during the early phase of admission were $5.10 \%$ and during the late phase was $3.70 \%$. There were 15 deaths in the group of patients who got themselves discharged against medical advice. Majority of COVID-19 deaths were due to respiratory failure $(81.57 \%)$, followed by respiratory failure with septic shock/sepsis and respiratory failure with septic shock/multi-organ dysfunction syndrome (MODS) (11.97\% each) (Table 2).

3.2. Association between sociodemographic, comorbidities, age, and the admission period on the outcome

The association between the period of admission (early $v s$. late) and death was significant; the proportion of deaths was higher during the pandemic's early period $(\mathrm{p}=0.046)$ (Table 3$)$. The proportions of deaths were significantly higher in males ( $p=0.02$ ), patients aged $\geq 50$ years, patients having hypertension, diabetes, CKD (all p-values $<0.001)$, COPD ( $p=0.033)$, coronary artery disease $p<0.001$ ), (Table 3$)$. In patients reporting fever $(\mathrm{p}<0.001)$, breathing difficulty ( $\mathrm{p}$ $<0.001)$, cough ( $<<0.001)$, fatigue $(\mathrm{p}<0.001)$, or higher grades of hypoxia ( $\mathrm{p}<0.001)$, mortality was significantly higher compared with the corresponding reference groups. The proportion of deaths were also significantly higher in patients with no contact history, abnormal chest X-ray ( $\mathrm{p}<0.001$ ), CT chest findings with COVID-19 pneumonia ( $\mathrm{p}<$ $0.001)$, ventilator, tracheostomy ( $p<0.001)$, patients not in self-prone position ( $\mathrm{p}<0.001$ ), and patients admitted to the ICU ( $\mathrm{p}<0.001)$. The re-admission rate was found to be $5.4 \%$ in this study. The results of the association between comorbidities and mortality are summarized in Table 3.

The subgroup analysis data that assessed the association between admission phase, comorbidities and age were similar to that observed in the primary analysis [Supplementary Table 1,2 and 3 present the data obtained from the subgroup analysis for the association of mortality with hypertension, diabetes and hypoxia, respectively].

\section{Discussion}

In this study, we set out to retrospectively evaluate the clinical and epidemiological aspects of COVID-19 in patients presenting to the MIOT International hospital in Chennai, Tamil Nadu. Our research indicates that the most common symptoms of COVID-19 patients were cough, fever, and myalgia. A total of $4.20 \%$ of patients died due to COVID-19, and this proportion of death was higher during the earlier phase of the pandemic. There was a significant association between comorbidities such as hypertension, diabetes, chronic kidney disease, COPD, CAD, and the proportion of deaths.

Epidemiological studies indicate a higher prevalence of SARS-CoV-2 infection in males compared to females. ${ }^{10,11}$ In a hospital-based study conducted in India, the incidence of COVID-19 in males was $93 \%{ }^{10}$ Similarly, an earlier cohort study conducted in Wuhan in patients

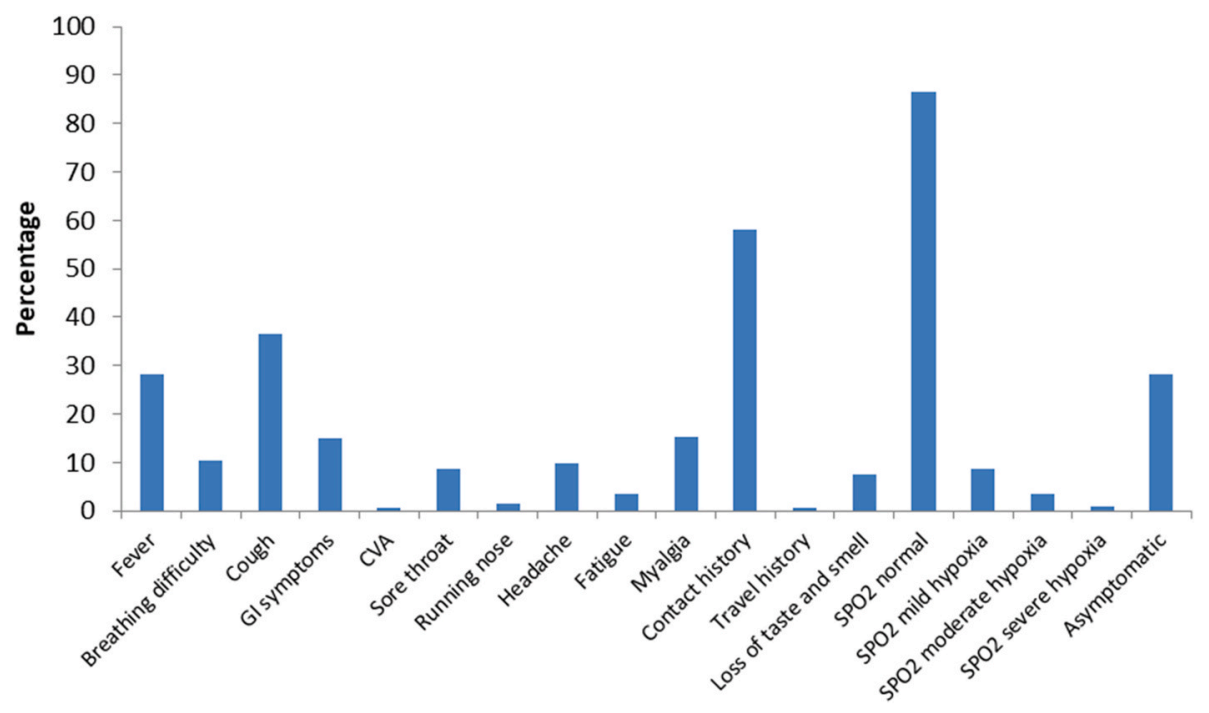

Fig. 1. Summary of the symptoms in COVID-19 patients. 


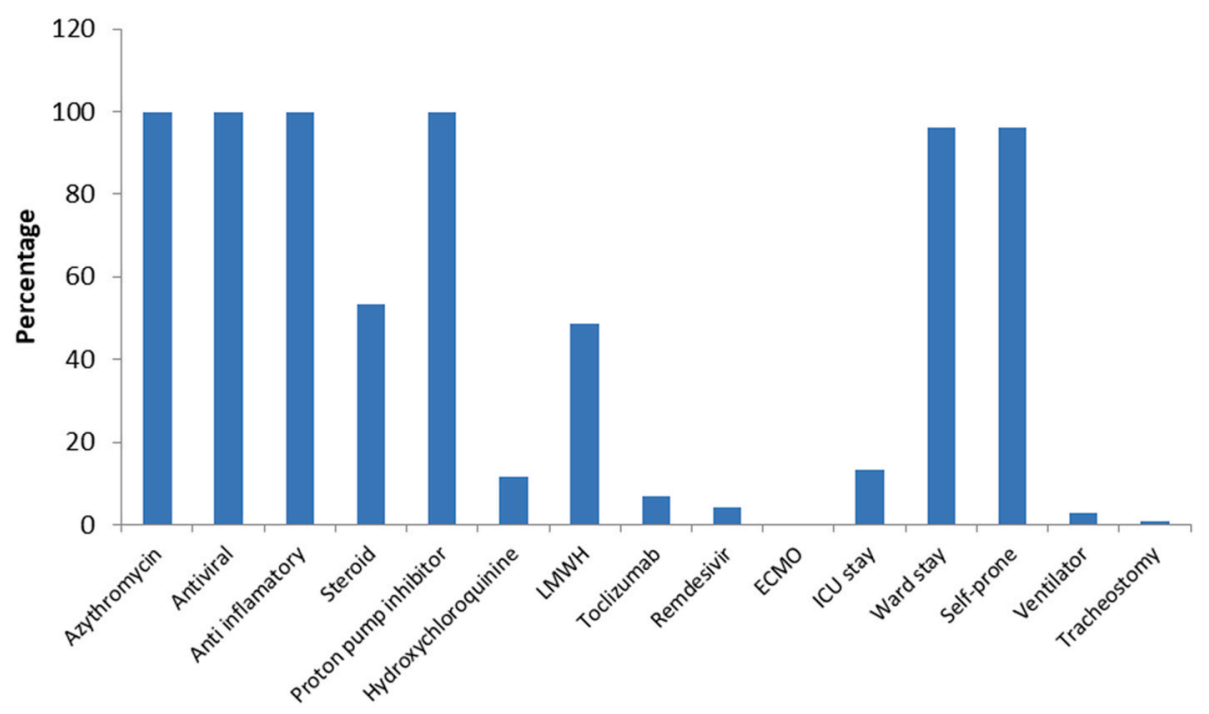

Fig. 2. Treatment administered to the patients.

Table 2

Causes of death in COVID-19 patients.

\begin{tabular}{lll}
\hline & Causes of death & Number \\
\hline 1 & Respiratory failure & 81 \\
2 & Respiratory failure with encephalopathy & 3 \\
3 & Respiratory failure \& myocarditis & 2 \\
4 & Respiratory failure with cardiac failure & 1 \\
5 & Cardiac arrest & 6 \\
6 & Respiratory failure with septic shock/sepsis & 17 \\
7 & Respiratory failure with septic shock and mods & 17 \\
8 & Deaths after DAMA (discharge against medical advice-exact cause & 15 \\
& not known) & 142 \\
\hline
\end{tabular}

confirmed to have COVID-19 reported an incidence of $77 \%$ in males. ${ }^{11}$ Results from our study corroborate these findings. In our study, approximately two-thirds of the patients who tested positive for COVID-19 were males $(69.2 \%)$. Studies have shown that during the early phase of the pandemic, patients aged $\geq 70$ years were at a higher risk and were subsequently isolated. ${ }^{12,13}$ However, it has been observed that the mean age has shifted towards the 50 years age group, ${ }^{14}$ and these corroborate with the results observed in our study; patients aged $\geq 50$ years were at a significantly higher risk of death from the SARS-CoV-2 infection compared to those below the age of 50 years.

In addition to age and gender, comorbidities have also presented to be risk factors in patients with SARS-CoV-2. ${ }^{15}$ Pieces of evidence demonstrate that patients with diabetes, hypertension, cardiovascular disease, and cerebrovascular disease are at a higher risk of death from SARS-CoV-2 infection. ${ }^{15-18}$ The SARS-CoV-2 virus uses the angiotensin-converting enzyme 2 (ACE2) receptor which is overexpressed in hypertensive and diabetic patients to enter the cells. ${ }^{17,19,20}$ In the study by Kumar et al., the risk of mortality in patients positive for COVID-19 and pre-existing diabetes was shown to be twice than that observed in non-diabetic patients. In a retrospective cohort study, Zhou et al. demonstrated that COVID-19 positive patients with pre-existing diabetes had 2.85 times the risk of mortality due to COVID-19 compared to patients without pre-existing diabetes, and those with comorbid hypertension had thrice the odds of mortality compared to non-hypertensive patients. ${ }^{18} \mathrm{~A}$ meta-analysis predicted that the likelihood of death was higher in patients with hypertension, diabetes, and cardiovascular disease. COVID-19 positive patients with comorbid cardiovascular disease had 3.32 times the risk of mortality than those without cardiovascular disease. ${ }^{15}$ Similarly, patients with immune and metabolic disorders had 2.39 times the risk of mortality because of COVID-19 compared to those without immune and metabolic disorders. ${ }^{13}$ Furthermore, patients with comorbidities require a longer time for recovery from the time of infection. ${ }^{12}$ Our study observed that patients with hypertension, diabetes, CKD, COPD, and CAD are at a significantly higher risk of mortality than those without these comorbidities. The findings in our study similarly corroborates findings from previous studies in literature.

Respiratory illnesses have also been shown to have a higher risk of mortality for patients with COVID-19. ${ }^{15}$ Patients with breathing difficulty ( $p<0.001$ ), fever ( $p<0.001$ ), higher grades of hypoxia ( $p<$ 0.001 ) showed a significant association with mortality. The severe cases that required ICU admission ( $\mathrm{p}<0.001$ ), tracheostomy ( $\mathrm{p}<0.001$ ), and mechanical ventilation $(\mathrm{p}<0.001)$ had a significant association with mortality in our study. Pneumonia was reported in $14.3 \%$ of patients, and abnormal chest X-ray was seen in $16.90 \%$ of patients. Several studies have reported COVID-19 pneumonia and ground-glass opacities found on chest X-ray in severe disease cases associated with a higher risk of mortality. These patients are also at higher risk of developing acute respiratory distress syndrome and experience "cytokine-storm" induced by the virus leading to mortality. ${ }^{11}$

Although no specific antiviral treatment is available for SARS-CoV-2, antimalarial drug hydroxychloroquine and anti-viral drugs such as remdesivir, lopinamir and ritonavir are being used for symptomatic management of infection. ${ }^{21-23}$ However, the data on treatment modalities are being evaluated, evolving, and updated on a real-time basis. We also observed a significant association between the pandemic phase (early $v$ s. late) with mortality (5.07\% deaths in the early phase $v s .3 .65 \%$ deaths in the late phase). The understanding of the pathogenesis, control, and treatment modalities for COVID-19 have improved over time and could have led to the possible reduction in severity and deaths during the later phase of the pandemic.

The mortality in this study, for patients admitted to a referral centre is relatively low for a hospital-based trial as observed in India. However, a prospective hospital-based surveillance study by Sami et al. reported $7 \%$ death rates in Iran. ${ }^{24}$ Additionally, a cohort study in US patients also reported $20 \%$ in-hospital mortality rate. ${ }^{25}$ Also considering that MIOT is a referral hospital, the number of sick patients referred are higher vs. secondary or tertiary care hospitals.

This was one of the largest studies conducted in South India during the COVID-19 pandemic. We analyzed the outcome based on the early and late phases of the pandemic as MIOT was one of the first hospitals to dedicate beds and personnel from the beginning of this pandemic for COVID-19 patients. All cases were identified in a timely and accurate 
Table 3

Association between the time of admission, sociodemographic variables/ comorbidities, symptoms, travel/contact history, investigations/therapy and outcome.

\begin{tabular}{|c|c|c|c|c|c|}
\hline \multirow[t]{2}{*}{ Variables } & & \multicolumn{4}{|c|}{ Outcomes Recorded } \\
\hline & & Dead & Alive & Total & $P$ value \\
\hline \multirow[t]{4}{*}{ DOA Category } & Early & 71 & 1329 & 1400 & 0.046 \\
\hline & & $(5.10)$ & $(94.90)$ & $(100.00)$ & \\
\hline & Late & 71 & 1874 & 1945 & \\
\hline & & $(3.70)$ & $(96.30)$ & $(100.00)$ & \\
\hline \multirow[t]{4}{*}{ Gender } & Female & 31 & 1000 & 1031 & 0.02 \\
\hline & & $(3.00)$ & $(97.00)$ & $(100.00)$ & \\
\hline & Male & 111 & 2203 & 2314 & \\
\hline & & $(4.80)$ & $(95.20)$ & $(100.00)$ & \\
\hline \multirow[t]{4}{*}{ Age group } & $<50$ & 18 & 1670 & 1688 & $<0.001$ \\
\hline & & (1.10) & $(98.90)$ & $(100.00)$ & \\
\hline & $\geq 50$ & 124 & 1533 & 1657 & \\
\hline & & $(7.50)$ & $(92.50)$ & $(100.00)$ & \\
\hline \multirow[t]{4}{*}{ Hypertension } & $\mathrm{N}$ & 60 & 2311 & 2371 & $<0.001$ \\
\hline & & $(2.50)$ & $(97.50)$ & $(100.00)$ & \\
\hline & $\mathrm{Y}$ & 82 & 892 & 974 & \\
\hline & & $(8.40)$ & $(91.60)$ & $(100.00)$ & \\
\hline \multirow[t]{4}{*}{ Diabetes } & $\mathrm{N}$ & 50 & 2055 & 2105 & $<0.001$ \\
\hline & & $(2.40)$ & $(97.60)$ & $(100.00)$ & \\
\hline & $\mathrm{Y}$ & 92 & 1148 & 1240 & \\
\hline & & $(7.40)$ & $(92.60)$ & $(100.00)$ & \\
\hline \multirow[t]{4}{*}{ Hypothyroidism } & $\mathrm{N}$ & 135 & 3116 & 3251 & 0.118 \\
\hline & & $(4.20)$ & $(95.80)$ & $(100.00)$ & \\
\hline & $\mathrm{Y}$ & $7(7.40)$ & 87 & 94 & \\
\hline & & & $(92.60)$ & $(100.00)$ & \\
\hline \multirow[t]{4}{*}{ CKD } & $\mathrm{N}$ & 131 & 3162 & 3293 & $<0.001$ \\
\hline & & $(4.00)$ & $(96.00)$ & $(100.00)$ & \\
\hline & $\mathrm{Y}$ & 11 & 41 & 52 & \\
\hline & & $(21.20)$ & $(78.80)$ & $(100.00)$ & \\
\hline \multirow[t]{4}{*}{ Bronchial Asthma } & $\mathrm{N}$ & 140 & 3107 & 3247 & 0.44 \\
\hline & & $(4.30)$ & (95.70) & $(100.00)$ & \\
\hline & $\mathrm{Y}$ & $2(2.00)$ & 96 & 98 & \\
\hline & & & $(98.00)$ & $(100.00)$ & \\
\hline COPD & $\mathrm{N}$ & 140 & 3198 & 3338 & 0.033 \\
\hline & & $(4.20)$ & $(95.80)$ & $(100.00)$ & \\
\hline & $\mathrm{Y}$ & 2 & 5 & 7 & \\
\hline & & $(28.60)$ & $(71.40)$ & $(100.00)$ & \\
\hline CAD & $\mathrm{N}$ & 109 & 3036 & 3145 & $<0.001$ \\
\hline & & $(3.50)$ & $(96.50)$ & $(100.00)$ & \\
\hline & $\mathrm{Y}$ & 33 & 167 & 200 & \\
\hline & & $(16.50)$ & $(83.50)$ & $(100.00)$ & \\
\hline Asymptomatic & $\mathrm{N}$ & 124 & 2278 & 2402 & $<0.001$ \\
\hline & & $(5.20)$ & $(94.80)$ & $(100.00)$ & \\
\hline & $\mathrm{Y}$ & 18 & 925 & 943 & \\
\hline & & $(1.90)$ & (98.10) & $(100.00)$ & \\
\hline Fever & $\mathrm{N}$ & 52 & 2345 & 2397 & $<0.001$ \\
\hline & & $(2.20)$ & $(97.80)$ & $(100.00)$ & \\
\hline & $\mathrm{Y}$ & 90 & 858 & 948 & \\
\hline & & $(9.50)$ & $(90.50)$ & $(100.00)$ & \\
\hline Breathing difficulty & $\mathrm{N}$ & 84 & 2913 & 2997 & $<0.001$ \\
\hline & & $(2.80)$ & $(97.20)$ & $(100.00)$ & \\
\hline & $\mathrm{Y}$ & 58 & 290 & 348 & \\
\hline & & $(16.70)$ & (83.30) & $(100.00)$ & \\
\hline Cough & $\mathrm{N}$ & 71 & 2049 & 2120 & 0.001 \\
\hline & & $(3.30)$ & (96.70) & (100.00) & \\
\hline & $\mathrm{Y}$ & 71 & 1154 & 1225 & \\
\hline & & $(5.80)$ & $(94.20)$ & $(100.00)$ & \\
\hline GI symptoms & $\mathrm{N}$ & 116 & 2727 & 2843 & 0.279 \\
\hline & & $(4.10)$ & $(95.90)$ & $(100.00)$ & \\
\hline & $\mathrm{Y}$ & 26 & 476 & 502 & \\
\hline & & $(5.20)$ & $(94.80)$ & $(100.00)$ & \\
\hline CVA & $\mathrm{N}$ & 141 & 3179 & 3320 & 1 \\
\hline & & $(4.20)$ & $(95.80)$ & $(100.00)$ & \\
\hline & $\mathrm{Y}$ & $1(4.00)$ & 24 & 25 & \\
\hline & & & $(96.00)$ & $(100.00)$ & \\
\hline Sore throat & $\mathrm{N}$ & 131 & 2925 & 3056 & 0.878 \\
\hline & & $(4.30)$ & (95.70) & $(100.00)$ & \\
\hline & $\mathrm{Y}$ & 11 & 278 & 289 & \\
\hline & & $(3.80)$ & $(96.20)$ & $(100.00)$ & \\
\hline Running nose & $\mathrm{N}$ & 141 & 3158 & 3299 & 0.721 \\
\hline & & $(4.30)$ & (95.70) & $(100.00)$ & \\
\hline & $\mathrm{Y}$ & $1(2.20)$ & & & \\
\hline
\end{tabular}

Table 3 (continued)

\begin{tabular}{|c|c|c|c|c|c|}
\hline \multirow[t]{2}{*}{ Variables } & & \multicolumn{4}{|c|}{ Outcomes Recorded } \\
\hline & & Dead & Alive & Total & $P$ value \\
\hline & & & $\begin{array}{l}45 \\
(97.80)\end{array}$ & $\begin{array}{l}46 \\
(100.00)\end{array}$ & \\
\hline \multirow[t]{2}{*}{ Headache } & $\mathrm{N}$ & $\begin{array}{l}135 \\
(4.50)\end{array}$ & $\begin{array}{l}2887 \\
(95.50)\end{array}$ & $\begin{array}{l}3022 \\
(100.00)\end{array}$ & 0.058 \\
\hline & $\mathrm{Y}$ & $7(2.20)$ & $\begin{array}{l}316 \\
(97.80)\end{array}$ & $\begin{array}{l}323 \\
(100.00)\end{array}$ & \\
\hline \multirow[t]{2}{*}{ Fatigue } & $\mathrm{N}$ & $\begin{array}{l}127 \\
(3.90)\end{array}$ & $\begin{array}{l}3102 \\
(96.10)\end{array}$ & $\begin{array}{l}3229 \\
(100.00)\end{array}$ & $<0.001$ \\
\hline & $\mathrm{Y}$ & $\begin{array}{l}15 \\
(12.90)\end{array}$ & $\begin{array}{l}101 \\
(87.10)\end{array}$ & $\begin{array}{l}116 \\
(100.00)\end{array}$ & \\
\hline \multirow[t]{2}{*}{ Myalgia } & $\mathrm{N}$ & $\begin{array}{l}125 \\
(4.40)\end{array}$ & $\begin{array}{l}2705 \\
(95.60)\end{array}$ & $\begin{array}{l}2830 \\
(100.00)\end{array}$ & 0.285 \\
\hline & $\mathrm{Y}$ & $\begin{array}{l}17 \\
(3.30)\end{array}$ & $\begin{array}{l}498 \\
(96.70)\end{array}$ & $\begin{array}{l}515 \\
(100.00)\end{array}$ & \\
\hline \multirow[t]{2}{*}{ Contact history } & $\mathrm{N}$ & $\begin{array}{l}114 \\
(8.10)\end{array}$ & $\begin{array}{l}1290 \\
(91.90)\end{array}$ & $\begin{array}{l}1404 \\
(100.00)\end{array}$ & $<0.001$ \\
\hline & $\mathrm{Y}$ & $\begin{array}{l}28 \\
(1.40)\end{array}$ & $\begin{array}{l}1913 \\
(98.60)\end{array}$ & $\begin{array}{l}1941 \\
(100.00)\end{array}$ & \\
\hline \multirow[t]{2}{*}{ Travel history } & $\mathrm{N}$ & $\begin{array}{l}140 \\
(4.20)\end{array}$ & $\begin{array}{l}3180 \\
(95.80)\end{array}$ & $\begin{array}{l}3320 \\
(100.00)\end{array}$ & 0.287 \\
\hline & $\mathrm{Y}$ & $2(8.00)$ & $\begin{array}{l}23 \\
(92.00)\end{array}$ & $\begin{array}{l}25 \\
(100.00)\end{array}$ & \\
\hline \multirow[t]{2}{*}{ Loss of taste and smell } & $\mathrm{N}$ & $\begin{array}{l}132 \\
(4.30)\end{array}$ & $\begin{array}{l}2965 \\
(95.70)\end{array}$ & $\begin{array}{l}3097 \\
(100.00)\end{array}$ & 1 \\
\hline & $\mathrm{Y}$ & $\begin{array}{l}10 \\
(4.00)\end{array}$ & $\begin{array}{l}238 \\
(96.00)\end{array}$ & $\begin{array}{l}248 \\
(100.00)\end{array}$ & \\
\hline SpO2 Normal & & $\begin{array}{l}52 \\
(1.80)\end{array}$ & $\begin{array}{l}2844 \\
(98.20)\end{array}$ & $\begin{array}{l}2896 \\
(100.00)\end{array}$ & $<0.001$ \\
\hline SpO2 mild hypoxia & & $\begin{array}{l}28 \\
(9.60)\end{array}$ & $\begin{array}{l}265 \\
(90.40)\end{array}$ & $\begin{array}{l}293 \\
(100.00)\end{array}$ & \\
\hline SpO2 moderate hypoxia & & $\begin{array}{l}43 \\
(35.20)\end{array}$ & $\begin{array}{l}79 \\
(64.80)\end{array}$ & $\begin{array}{l}122 \\
(100.00)\end{array}$ & \\
\hline SpO2 severe hypoxia & & $\begin{array}{l}19 \\
(55.90)\end{array}$ & $\begin{array}{l}15 \\
(44.10)\end{array}$ & $\begin{array}{l}34 \\
(100.00)\end{array}$ & \\
\hline \multirow[t]{2}{*}{ CXR abnormal } & $\mathrm{N}$ & $\begin{array}{l}34 \\
(1.20)\end{array}$ & $\begin{array}{l}2747 \\
(98.80)\end{array}$ & $\begin{array}{l}2781 \\
(100.00)\end{array}$ & \\
\hline & $\mathrm{Y}$ & $\begin{array}{l}108 \\
(19.10)\end{array}$ & $\begin{array}{l}456 \\
(80.90)\end{array}$ & $\begin{array}{l}564 \\
(100.00)\end{array}$ & \\
\hline \multirow[t]{2}{*}{$\begin{array}{l}\text { CT chest findings } \\
\text { COVID pneumonia }\end{array}$} & $\mathrm{N}$ & $\begin{array}{l}94 \\
(3.30)\end{array}$ & $\begin{array}{l}2773 \\
(96.70)\end{array}$ & $\begin{array}{l}2867 \\
(100.00)\end{array}$ & \\
\hline & $\mathrm{Y}$ & $\begin{array}{l}48 \\
(10.00)\end{array}$ & $\begin{array}{l}430 \\
(90.00)\end{array}$ & $\begin{array}{l}478 \\
(100.00)\end{array}$ & \\
\hline \multirow[t]{2}{*}{ Self-prone } & $\mathrm{N}$ & $\begin{array}{l}74 \\
(56.10)\end{array}$ & $\begin{array}{l}58 \\
(43.90)\end{array}$ & $\begin{array}{l}132 \\
(100.00)\end{array}$ & $<0.001$ \\
\hline & $\mathrm{Y}$ & $\begin{array}{l}68 \\
(2.10)\end{array}$ & $\begin{array}{l}3145 \\
(97.90)\end{array}$ & $\begin{array}{l}3213 \\
(100.00)\end{array}$ & \\
\hline \multirow[t]{2}{*}{ Ventilator } & $\mathrm{N}$ & $\begin{array}{l}59 \\
(1.80)\end{array}$ & $\begin{array}{l}3184 \\
(98.20)\end{array}$ & $\begin{array}{l}3243 \\
(100.00)\end{array}$ & $<0.001$ \\
\hline & $\mathrm{Y}$ & $\begin{array}{l}83 \\
(81.40)\end{array}$ & $\begin{array}{l}19 \\
(18.60)\end{array}$ & $\begin{array}{l}102 \\
(100.00)\end{array}$ & \\
\hline \multirow[t]{2}{*}{ Tracheostomy } & $\mathrm{N}$ & $\begin{array}{l}124 \\
(3.70)\end{array}$ & $\begin{array}{l}3194 \\
(96.30)\end{array}$ & $\begin{array}{l}3318 \\
(100.00)\end{array}$ & $<0.001$ \\
\hline & $\mathrm{Y}$ & $\begin{array}{l}18 \\
(66.70)\end{array}$ & $\begin{array}{l}9 \\
(33.30)\end{array}$ & $\begin{array}{l}27 \\
(100.00)\end{array}$ & \\
\hline \multirow[t]{2}{*}{ Steroid } & $\mathrm{N}$ & $\begin{array}{l}20 \\
(1.30)\end{array}$ & $\begin{array}{l}1536 \\
(98.70)\end{array}$ & $\begin{array}{l}1556 \\
(100.00)\end{array}$ & $<0.001$ \\
\hline & $\mathrm{Y}$ & $\begin{array}{l}122 \\
(6.80)\end{array}$ & $\begin{array}{l}1667 \\
(93.20)\end{array}$ & $\begin{array}{l}1789 \\
(100.00)\end{array}$ & \\
\hline \multirow[t]{2}{*}{ Hydroxychloroquinine } & $\mathrm{N}$ & $\begin{array}{l}115 \\
(3.90)\end{array}$ & $\begin{array}{l}2846 \\
(96.10)\end{array}$ & $\begin{array}{l}2961 \\
(100.00)\end{array}$ & 0.0067 \\
\hline & $\mathrm{Y}$ & $\begin{array}{l}27 \\
(7.00)\end{array}$ & $\begin{array}{l}357 \\
(93.00)\end{array}$ & $\begin{array}{l}384 \\
(100.00)\end{array}$ & \\
\hline \multirow[t]{2}{*}{ LMWH } & $\mathrm{N}$ & $\begin{array}{l}50 \\
(2.90)\end{array}$ & $\begin{array}{l}1669 \\
(97.10)\end{array}$ & $\begin{array}{l}1719 \\
(100.00)\end{array}$ & $<0.001$ \\
\hline & $\mathrm{Y}$ & $\begin{array}{l}92 \\
(5.70)\end{array}$ & $\begin{array}{l}1534 \\
(94.30)\end{array}$ & $\begin{array}{l}1626 \\
(100.00)\end{array}$ & \\
\hline \multirow[t]{2}{*}{ Tocilizumab } & $\mathrm{N}$ & $\begin{array}{l}102 \\
(3.30)\end{array}$ & $\begin{array}{l}3012 \\
(96.70)\end{array}$ & $\begin{array}{l}3114 \\
(100.00)\end{array}$ & $<0.001$ \\
\hline & $\mathrm{Y}$ & $\begin{array}{l}40 \\
(17.30)\end{array}$ & $\begin{array}{l}191 \\
(82.70)\end{array}$ & $\begin{array}{l}231 \\
(100.00)\end{array}$ & \\
\hline \multirow[t]{2}{*}{ Remdesivir } & $\mathrm{N}$ & $\begin{array}{l}130 \\
(4.10)\end{array}$ & $\begin{array}{l}3070 \\
(95.90)\end{array}$ & $\begin{array}{l}3200 \\
(100.00)\end{array}$ & 0.031 \\
\hline & $\mathrm{Y}$ & $\begin{array}{l}12 \\
(8.30)\end{array}$ & $\begin{array}{l}133 \\
(91.70)\end{array}$ & $\begin{array}{l}145 \\
(100.00)\end{array}$ & \\
\hline
\end{tabular}


Table 3 (continued)

\begin{tabular}{|c|c|c|c|c|c|}
\hline \multirow[t]{2}{*}{ Variables } & & \multicolumn{4}{|c|}{ Outcomes Recorded } \\
\hline & & Dead & Alive & Total & $P$ value \\
\hline \multirow[t]{2}{*}{ ECMO } & $\mathrm{N}$ & $\begin{array}{l}141 \\
(4.20)\end{array}$ & $\begin{array}{l}3203 \\
(95.80)\end{array}$ & $\begin{array}{l}3344 \\
(100.00)\end{array}$ & 0.042 \\
\hline & $\mathrm{Y}$ & $\begin{array}{l}1 \\
(100.00)\end{array}$ & $0(0)$ & $\begin{array}{l}1 \\
(100.00)\end{array}$ & \\
\hline \multirow[t]{2}{*}{ Readmission } & $\mathrm{N}$ & $\begin{array}{l}140 \\
(4.20)\end{array}$ & $\begin{array}{l}3168 \\
(95.80)\end{array}$ & $\begin{array}{l}3308 \\
(100.00)\end{array}$ & 0.67 \\
\hline & $\mathrm{Y}$ & $2(5.40)$ & $\begin{array}{l}35 \\
(94.60)\end{array}$ & $\begin{array}{l}37 \\
(100.00)\end{array}$ & \\
\hline
\end{tabular}

$P$-values are derived from the Pearson Chi-Square test and Fisher's exact test as appropriate.

Data presented as $\mathrm{n}(\%)$.

DOA: date of admission; N: no; Y: yes.

manner using RT-PCR, which helped to identify cases adequately. However, the results of this study must be interpreted with certain limitations kept in mind. Being a single-centre study in Chennai, the results need to be interpreted cautiously when generalizing it to the overall population. This being a private hospital providing specialized quaternary care, only patients referred to this hospital have been recorded, thereby underestimating the true incidence and mortality of COVID-19. Another limitation of the study was our inability to assess the impact of obesity as measuring body weights of patients was not possible owing to time constraints for the staff who managed wheelchair- and trolley-bound patients during the COVID-19 pandemic. Furthermore, those cases which could not be admitted due to the lack of ICU beds could lead to biased estimation of the true incidence. As the case definition evolved during the pandemic, there could have been misclassification of cases.

\section{Conclusions}

In conclusion, our study showed similar results to those seen in other studies on COVID-19 regarding the clinical presentation and prognosis. We found a difference in the incidence of disease and mortality between the early and late phases of the pandemic, indicating better awareness and disease management during the later phase of the pandemic in this study. In comparison to other hospital based studies, this series of patients appear to have had a lower mortality rate for COVID-19. Comorbidities like hypertension, diabetes, CKD, CAD, and COPD were risk factors for poor prognosis of the disease. In severe cases of COVID19 pneumonia abnormal radiological findings were found to correlate with severity of disease. ICU admission and ventilatory support were frequently required for the severe cases. In the absence of preventive measures and evolving treatment modalities based on the current understanding, strict hygienic practices and appropriate protocols must be followed.

\section{Funding}

This research did not receive any specific grant from funding agencies in the public, commercial, or not-for-profit sectors.

\section{Declaration of competing interest}

Authors declare no conflict of interest for this article.

\section{Acknowledgment}

The authors would like to thank MD. Najeeb Ashraf, Ivan Dsouza and Leena Patel to provide writing and editorial support and Vidula Bhole for providing statistical analysis support towards development of the manuscript. The authors also would like to thank Samir Pershad, S. Balaji, K. Manoj Kumar, D. Aruna Karunya, Merin S, Money and P. Arumugam towards their support for data collection.

\section{Appendix A. Supplementary data}

Supplementary data to this article can be found online at https://doi. org/10.1016/j.cegh.2021.100751.

\section{References}

1 Pascarella G, Strumia A, Piliego C, et al. COVID-19 diagnosis and management: a comprehensive review. J Intern Med. 2020;288(2):192-206.

2 Statement on the Meeting of the International Health Regulations (2005) Emergency Committee Regarding the Outbreak of Novel Coronavirus 2019 (N-CoV) on 23 January 2020 (who.Int) [Last accessed December 2020].

3 Sohrabi C, Alsafi Z, O'Neill N, et al. World Health Organization declares global emergency: a review of the 2019 novel coronavirus (COVID-19). Int J Surg. 2020;76: 71-76.

4 WHO coronavirus disease (COVID-19) dashboard [Last accessed January 2021] https ://covid19.who.int/.

5 Release of District Level Factsheets for Nfhs-5(2019-20) Phase-I States/uts. Available at: MoHFW | Home [Last accessed December 2020].

6 Yousefi B, Valizadeh S, Ghaffari H, Vahedi A, Karbalaei M, Eslami M. A global treatments for coronaviruses including COVID-19. J Cell Physiol. 2020;235(12): 9133-9142.

7 Singh Virendra, Khatana Shruti, Gupta Pranav. Blood gas analysis for bedside diagnosis. Natl J Maxillofac Surg. 2013;4(2):136-141.

8 Manna S, Wruble J, Maron SZ, et al. COVID-19: a multimodality review of radiologic techniques, clinical utility, and imaging features. Radiol Cardiothorac Imaging. 2020;2 (3), e200210.

9 Overview of COVID-19 Section_43 (nih.Gov). [Last accessed January 2021].

10 Mohan A, Tiwari P, Bhatnagar S, et al. Clinico-demographic profile \& hospital outcomes of COVID-19 patients admitted at a tertiary care centre in north India. Indian J Med Res. 2020;152(1 \& 2):61-69.

11 Huang C, Wang Y, Li X, et al. Clinical features of patients infected with 2019 novel coronavirus in Wuhan, China. Lancet. 2020;395(10223):497-506.

12 Osama T, Pankhania B, Majeed A. Protecting older people from COVID-19: should the United Kingdom start at age 60? J R Soc Med. 2020;113(5):169-170.

13 Murthy S, Gomersall CD, Fowler RA. Care for critically ill patients with COVID-19. J Am Med Assoc. 2020;323(15):1499-1500.

14 Zhu S, Huang Y, Tang W, Nussler AK, Zheng F. Increasing age, the existence of comorbidities, and corticosteroid treatment in combination with antiviral therapy prolongs the recovery of SARS-COV-2-infected patients, measured as the conversion from positive to negative rtPCR: a 239 patients' retrospective study. Front Med. 2020; 7:575439.

15 Khan MMA, Khan MN, Mustagir MG, Rana J, Islam MS, Kabir MI. Effects of underlying morbidities on the occurrence of deaths in COVID-19 patients: a systematic review and meta-analysis. J Glob Health. 2020;10(2), 020503.

16 Kumar A, Arora A, Sharma P, et al. Is diabetes mellitus associated with mortality and severity of COVID-19? A meta-analysis. Diabetes Metab Syndr. 2020;14(4):535-545.

17 Cristelo C, Azevedo C, Marques JM, Nunes R, Sarmento B. SARS-CoV-2 and diabetes: new challenges for the disease. Diabetes Res Clin Pract. 2020;164:108228.

18 Zhou F, Yu T, Du R, et al. Clinical course and risk factors for mortality of adult inpatients with COVID-19 in Wuhan, China: a retrospective cohort study. Lancet. 2020;395(10229):1054-1062.

19 Lu R, Zhao X, Li J, et al. Genomic characterisation and epidemiology of 2019 novel coronavirus: implications for virus origins and receptor binding. Lancet. 2020;395 (10224):565-574.

20 Hoffmann M, Kleine-Weber H, Schroeder S, Krüger N, Herrler T, Erichsen S, et al. SARS-CoV-2 cell entry depends on ACE2 and TMPRSS 2 and is blocked by a clinically proven protease inhibitor. Cell. 2020;181(2):271-280. e8.

21 Saqrane S, El Mhammedi MA. Review on the global epidemiological situation and the efficacy of chloroquine and hydroxychloroquine for the treatment of COVID-19. New Microbes New Infect. 2020;35:100680.

22 Chu CM, Cheng VC, Hung IF, et al. Role of lopinavir/ritonavir in the treatment of SARS: initial virological and clinical findings. Thorax. 2004;59(3):252-256.

23 Sheahan TP, Sims AC, Leist SR, et al. Comparative therapeutic efficacy of remdesivir and combination lopinavir, ritonavir, and interferon beta against MERS-CoV. Nat Commun. 2020;11(1):222.

24 Sami R, Soltaninejad F, Amra B, et al. A one-year hospital-based prospective COVID19 open-cohort in the Eastern Mediterranean region: the Khorshid COVID Cohort (KCC) study. PloS One. 2020;15(11), e0241537.

25 Rosenthal N, Cao Z, Gundrum J, Sianis J, Safo S. Risk factors associated with inhospital mortality in a US national sample of patients with COVID-19. JAMA Netw Open. 2020;3(12), e2029058. 